\title{
Belajar Melalui Pengalaman Historis (BMPH) pada Siswa SMP di Kabupaten Sigi Sulawesi Tengah
}

\author{
Misnah \\ Fakultas Keguruan dan Ilmu Pendidikan UniversitasTadulako \\ email: misnah@untad.ac.id
}

\begin{abstract}
ABSTRAK
BMPH singkatan dari Belajar Melalui pengalaman Historis merupakan sebuah paradigma mengenai pengalaman dari latar belakang sejarah yang menjadi pengalaman dalam kehidupan yang akan dijadikan sebagai sumber pembelajaran sejarah bagi siswa SMP di Kabupaten Sigi Sulawesi Tengah. Saat ini dengan perkembangan arus globalisasi sangat penting bagi peserta didik mencintai culture untuk menanamkan kesadaran pentingnya pengalaman melalui budaya dapat digunakan peserta didik sebagai sebuah proses pembelajaran belajar dari lingkungan historis kearifan budaya lokal daera pada masyarakat etnik di Kabupaten Sigi Sulawesi Tengah. BMPH bertujuan untuk memberikan pengetahuan dan pemahaman mengenai BMPH kepada peserta didik di SMP di kabupaten Sigi SMP kelas 1 dan siswa dapat mempraktekan dan memiliki kepedulian, pentingnya melestarikan budaya historis pada kehidupan sehari-hari. Metode pelaksanaan dilakukan dengan caramelakukan penyuluhan di depan kelas, dan membawa peserta didik ke lokasi situs lumpang batu Vatu Nonju sebagai wujud historis budaya pada masyarakat etnik kaili yang penting diwariskan melalui pembelajaran.
\end{abstract}

Kata Kunci: Belajar, pengalaman, Historis

\begin{abstract}
BMPH stands for Learning through Historical Experience is a paradigm regarding experiences from historical backgrounds that become experiences in life that will be used as a source of history learning for junior high school students in Sigi Regency, Central Sulawesi. At present with the development of globalization currents it is very important for students to love culture to instill awareness of the importance of experience through culture can be used by students as a learning process of the historical environment of local cultural wisdom daera in ethnic communities in Sigi Regency, Central Sulawesi. BMPH aims to provide knowledge and understanding of BMPH to students in junior high school in Sigi district, junior high school class 1 and students can practice and care, the importance of preserving historical culture in everyday life. The method of implementation is carried out by conducting counseling in front of the class, and bringing students to the location of the Vatu Nonju stone mortar site as a historical manifestation of culture in the important ethnic Kaili community inherited through learning.
\end{abstract}

Keywords: Learning, experience, historical 


\section{PENDAHULUAN}

Pandangan mengenai konsep histori bahwa dalam perjalanan sejarah menempatkan manusia memiliki peran penting sebagai pelaku sejarah sebagai agen perubahan (change). Pernyataan ini didukung oleh pendapat Supriatna (2016, hlm 105) sejarah konvensional mengagngkat peran manusia sebagai pelaku utama dalam prose perputarnya riodisasi sejarah. Ahmad (2017) menguraikan bahwa upaya membangun kembali budaya Indonesia yaitu dengan cara menghadirkan prespektif historis mengenai interaksi dalam kehidupan bermasyarakat. Dengan demikian dinamika melalui kajian historis memberikan gambaran mengenai kehidupan sosial budaya yang memberikan gambaran kehidupan yang dinamis, terbuka, dan menyesuaikan sesuai dengan zamanya. Menurut pandangan susanto (2014, hlm323) menguraikan bahwa secara umum mengenai sebuah budaya kontekstual atau gagasan -gagasan setempat yang bersifat bijaksana, penuh kearifan, bernilai baik yang diwariskan pada generasi berikutnya yang terwujud nyata antara lain: 1) Tekstual berupa system nilai, tata cara yang dituangkan dalam bentuk tulisan melalui kitab tradisional, primbon, lontara atau daun lontar, 2) Bangunan/ Arsitektur dan 3) Benda Cagar Budaya/ tradisional Bentuk kearifan lokal tersebut merupakan konsep kontekstual yang bisa disajikan kepada peserta didik untuk menghasilkan pembelajaran yang dikaji dalam kehidupan bermasyarakat melalui kajian historis.

Undang-undang Nomor 20 tahun 2003 mengenai Sistim Pendidikan Nasional menyebutkan bahwa mengembangkan kemampuan dan menbentuk watak serta peradaban bangsa dan berkembangnya potensi peserta didik agar menjadi manusia yang beriman, bertakwa Kepada Tuhan Yang Maha Esa, berahlak mulia, kreatif, cakap, mandiri dan menjadi warga Negara yang demokrasi dan bertanggung jawab. Pendidikan yang baik akan menghasilkan output yang memiliki katakter yang unggul menurut Furqon (2014 hlm 4) bahwa penerapan pendidikan yang kental dengan kearifan lokal yang bersifat tradisional sebagai sumber inovasi dan keterampilan yang dapat diberdayakan melalui proses pendidikan dalam rangka mewujudkan tujuan pendidikan. Untuk mengembangka karakter didukung oleh pentingnya sebuah budaya yang menjadi karakter yang menjadi cir khas sebuah daerah untuk mewujudkan tercapainya tujuan pendidikan Nasional.

Menurut pendapat Herlina ( 2018 hlm 128-128) mengangkat budaya lokal sebagai bagian terintegrasi dalam proses pembelajaran merupakan tuntutan zaman yang akan ennjabarkan bahwa kebudayaan nasional adalah puncak dari kebudayaan daerah, melalui pendidikan berbagai nilai-nilai keunggulan budaya masa lampau diperkenalkan melalui budaya lampau, dikaji dan dikembangkan menjadi budaya yang diwariskan menjadi budaya dirinya, masyarakat, yang sesuai dengan perkembangan zamanya. Pada paparan tersebut mengambarkan bahwa budaya yang akan dikembangkan melalui pewarisan adalah budaya nasional yang merupakan budaya daerah, dengan demikian dalam setiap materi pelajaran IPS di SMP pentingnya memperkenalkan budaya daerah (lokal) sebagai implementasi pelestarian budaya. Berdasarkan pengamatan yang dilakukan peneliti, bahwa dalam proses pembelajaran 
siswa di sekolah belum mengetahui mengenai kajian historis culture situs lumpang batu (Vatu Nonju), minimnya pengetahuan siswa mengenai kebudayaan lokal yang ada di daerah. Dengan demikian melalui Melalui (MPHS) Belajar Melalui Pengalaman histori merupakan sebuah konsep mengenai manusia merupakan bagian dari alam yang yang pada konsep tematiknya manusia sebagai pelaku sejarah yang akan dikaji melalui kajian budaya yaitu lumpang batu (Vatu Nonju) yang memiliki manfaat bagi siswa di lingkungan SMP di Kabupaten Sigi Sulawesi Tengah, sebagai salah satu sumber pembelajaran kontekstual. Pentingnya menerapkan pembelajaran melalui program MPHS merumuskan penerapan pembelajaran IPS di SMP di Kabupaten sigi berbasis culture budaya lumpang batu (Vatu Nonju).

Penerapan MPHS di sekolah merupakan hal yang penting saat ini dengan perkembangan globalisasi yang memberikan akses dan sumber informasi nyata bagi peserta didik, mencintai culture kondisi saat ini harus dimulai pada kecintaatn terhadap budaya daerah. Kecintaan terhadap historis budaya daerah salah satu factor yang sangat menentukan menghasilkan peserta didik yang memiliki kesadaran mengenai pentingnya budaya daerah dan pewarisan budaya daerah salah satunya adalah melalui pendidikan yaitu Belajar Melalui Pengalaman Historis (MPHS) budaya daerah merupakan salah satu upaya untuk membangun karakterbangsa. Melalui MPHS memperkenalkan culture kepada peserta didik, diajak untuk berfikir kritis melalui historis culture lokal wisdom, mengakses informasi melalui lingkungan historis untuk memperoleh pengetahuan melalui peradaban masa lalu. Pengembangan kata tanya dengan kata mengapa bisa menjadi analisis berfikir kritis bagi peserta didik yang disesuaikan dengan jenjang pendidikan mereka.

\section{METODE}

Menyadari urgenya historis culture bagi siswa di sekolah yang akan di desain dalam pengembangan bahan ajar yang akan dijadikan sebagai sumber pembelajaran untuk memberikan bekal bagi peserta didik menjadi warga Negara yang menjunjung tinggi nilai-nilai budaya historis dan peserta didik belajar melalui pengalaman kehidupan sehari-hari dalam dunia nyata sebagai materi pelajaran. Melalui PMPH di sekolah akan menghasilkan peserta didik yang memiliki karakter yang berwawasan cinta terhadap historis culture dalam pengetahuan, kesadaran dan aplikasi hidup menjaga warisan budaya yang diperoleh mellaui proses pembelajaran PMPH.

Kegiatan penyuluhan ini dilakukan oleh para dosen dan dibantu oleh tohoh adat penjaga situs lumpang batu (vatu Nonju), dalam bentuk kegiatan melakakan kunjungan karya wisata di lokasi situs Vatu Nonju di Desa Loru. Sasaran dari Kegiatan pengabdian masyarakat ini merupakan wujud kepedulian peneliti menyikapi kurangnya pengetahuan siswa SMP kelas 1 di kabupaten Sigi mengenai historis culture yang memiliki nilai-nilai yang unggul dijadikan sebagai sumber pembelajaran di luar kelas, sehingga pelatihan melalui kunjungan karya wisata sangat penting dilaksanakan dengan menyikapi arus iptek yang luar bisa bergerak sehingga pentingnya kegiatan pengabdian ini untuk dilaksanakan. 
Untuk kelancaran penyuluhan yang akan kami lakasanakan melalui PMPH kegiatan diuraikan sebagai berikut.

1. Tahap Persiapan
a. Analisis Situasi
b. Melakukan koordinasi untuk melaksanakan kegiatan
c. Menyusun persiapan pengusulan Proposal
d. Pengajuan permohonan pelaksanaan kegiatan

2. Tempat Pelasanaan

a. Tempat : di desa Loru Situs Lumpang Batu

b. Pukul : 08- Selesai

3. Pelakasanaan adalah dosen dan penjaga situs Lumpang Batu

4. Langka-Langkah Pelaksanaan

a. Kegiatan

- Kegiatan pendahuluan perkenalan, penjelasan mengenai situs lumpang batu

b. Kegiatan Inti adalah siswa melakukan pengamatan terhadap lokasi situs lumpang batu dan baruga (tempat musyawarah) yang ada di lokasi situs lumpang batu, Penyampaian materi yang disampaikan oleh dosen dan penjaga situs pada saat siswa melakukan pengamatan hasil budaya situs lumpang batu, Tanya jawab, dan siswa melakukan diskusi terhadap hasil pengamatan mereka melalui diskusi kelompok yang dipandu oleh dosen dan penjaga situs.

5. Metode : karya wisata

6. Media : Situs lumpang batu Vatu Nonju

7. Evaluasi :

a. Pre Tes

b. Post tes

8. Refleksi 


\section{HASIL}

Pelaksanaan kegiatan bagi peserta didik di sekolah menengah pertama (SMPN) 1 kabupaten Sigi
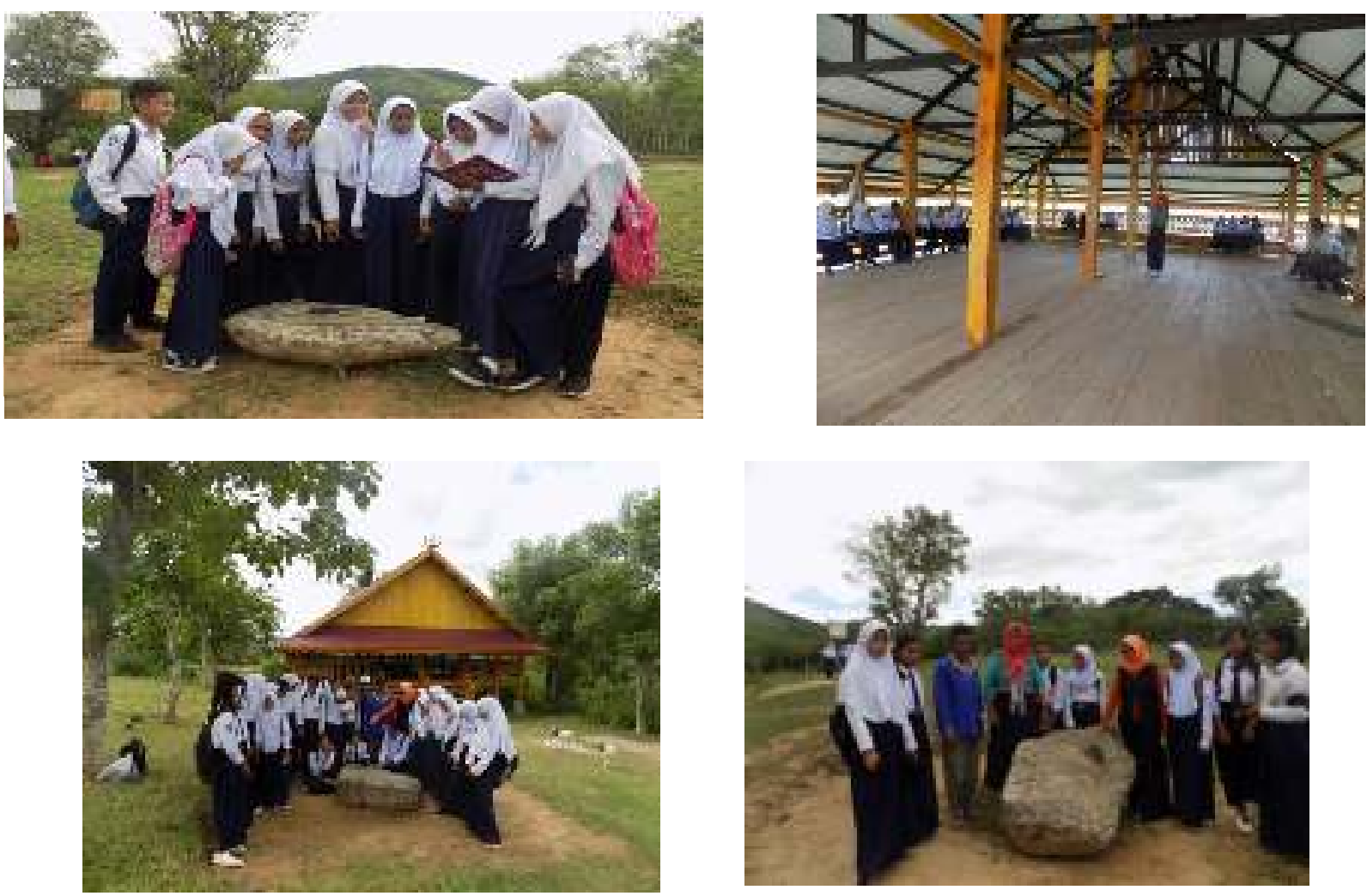

Gambar 1. Kegiatan Pembelajaran Historis Culture Situs Lumpang batu (vatu Nonju)

\section{Deskripsi umum mengenai kegiatan pembelajaran melalui Situs Lumpang Batu :}

Pelaksanaan kegiatan BMPH yang dilaksanakan pada sekolah SMP 1 kabupaten Sigi yang dilaksanakan di Desa Loru Kabupaten Sigi Propinsi Sulawesi Tengah merujuk pada 4 kegiatan yang dilaksanakan Action Research yaitu: Perencanaan, tindakan, observasi, evaluasi dan refleksi yang dilaksanakan sebagai berikut:

1. Perencanaan

a. Perizinan yang ditujukan ke Fakultas Keguruan dan Ilmu Pendidikan yang akan ditujukan kepada Sekolah Menenfgah Pertama (SMPN) 1 Kabupaten Sigi Sulawesi Tengah.

b. Sosialisasi program penyuluhan BMPH yang dilaksanakan di sekolah Menengah Pertama (SMPN) 1 Kabupaten Sigi Sulawesi Tengah.

c. Penyusunan kegiatan Program BMPH.

2. Pelaksanaan

Kegiatan yang dilaksanakan pada kegiatan inti adalah implementasi program kegiatan mengunjungi situs lumpang batu melalui program BMPH yang dilaksanakan adalah sebagai berikut:

a. Pengenalan pendidikan program BMPH kepada siswa SMPN 1 kabupaten Sigi Sulawesi Tengah 
b. Edukasi Mengenai Situs Lumpang batu, melalui pengamatan siswa langsung terhadap pengenalan lingkungan situs lumpang batu

c. Melakukan Inventasisasi pada nilai-nilai historis Budaya situs Lumpang Batu

d. Mengidentifikasi Nilai-nilai Historis pada budaya situs lumpang batu

e. Melakukan Wawancara kepada narasumber penjaga situs lumpang batu mengenai Kapan, Siapa, dimana, Mengapa dan apa manfaat situs lumpang batu pada kajian historis.

f. Mendiskusikan bersama, dosen, siswa, narasumber penjaga situs lumpang batu terhadap hasil identufikasi peserta didik mengenai data historis budaya situs lumpang Batu di situs Vatu Nonju.

g. Mempraktekan bentuk Simpati terhadap lingkungan situs Vatu Nonju dengan cara melakukan pembersihan lingkungan yaitu mengangkat beberapa sampah-sampah yang ada di lingkungan sekitar situs Lumpang batu situs vatu Nonju.

3. Observasi, Monitoring dan evaluasi

Observasi dilakukan terhadap proses implementasi kegiatan yang dilaksanakan berdasarkan indikator chek list berdasarkan kriterian yang telah di susun berdasarkan indikatior ketercapaian program BMPH, berikut adalah kegiatan evaluasi yang dilaksanakan yaitu memberiakn bentuk tes dalam bentuk soal pre test dan post tes dalam kegiatan penilaian yang dilaksanakan, bahwa siswa memiliki peningkatan pengetahuan, sikap dan karakter yang baik setelah selesai mengikuti kegiatan program BMPH.

4. Refleksi

Refleksi ini dilaksanakan dengan dasar untuk meninjau kembali terhadap kegiatan yang telah dilaksanakan dengan melakukan peninjauan kembali terhadap kelemahan-kelemahan atau dampak postif terhadap kegiatan yang telah selesai dilaksanakan dengan tujuan untuk menghasilkan rekomendasi kepada sekolah, Dinas Pendidikan terkait keberlanjutan program BMPH.

\section{PEMBAHASAN}

Kegiatan pelaksanaan Belajar Melalui Pengalaman Historis (BMPH) pada Siswa SMP Di Kabupaten Sigi Sulawesi Tengah yang dilaksanakan dengan peserta berjumlah 25 orang menghasilkan peningkatan pengetahuan, ketrampilan dan sikap spserta didik mengenai pentingnya menjaga lingkungan melalui kegiatan program pembelajaran BMPH yang dilaksanmakan di situs lumpang batu di desa Loru kabupaten Sigi Sulawesi Tengah. Berdasarkan hasil wawancara dengan siswa yang bernama Yoan bahwa menguraikan pendapatnya melalui pembelajaran program BMPH banyak kebaharuan mengenai asal usul dan manfaat situs lumpang batu pada masa batu pra aksara di Sulawesi Tengah khususnya di kabupaten Sigi yang mereka dapatkan melalui pembelajaran kunjungan langsung ke situs lumpang batu. Pernyataan ini di dukung oleh Guru bidang studi IPS Damiyatun memaparkan pada materi kelas 1 menjelaskan bahwa melalui pembelajaran historis culture dalam bentuk kunjungan langsung ke situs lumpang batu di 
desa loru, siswa lebih mengalami peningkatan pada pengetahuan mengenai materi kelas 1 yaitu Kehidupan masyarakat Indonesia pada masa Pra -Aksara pada pengembangan materi mengenai nilainilai budaya masa pra aksara di Indonesia dan pada pembelajaran BMPH siswa memiliki pengetahuan yang baru mengenai nilai-nilai budaya pada masa pra aksara di Sulawesi tengah yaitu dalam bentuk peninggalan megalit situs Lumpang batu di desa Loru kabupaten sigi Sulawesi Tengah.

Kegiatan pembelajaran kontekstual langsung berkunjung ke lokasi situs peninggalan budaya pada masa lampau memberikan pembelajaran langsung kepada peserta didik, menurut pendapat Printina (2017 hlm 1) menjelaskan bahwa salah satu cara untuk membentu karakter peserta didik dalam pembelajaran sejarah dengan cara menggunakan pembiasaan penggunaan nilai-nilai positif yang syarat dengan nilainilai moral yang di akses dari budaya bangsa Indonesia. Berdasarkan uraian tersebut memberikan pemahaman bahwa pentingnya memanfaatkan konten budaya berbasis culture historis sebagai salah satu sumber dalam pembelajaran sejarah. Pada nilai-nilai historis dalam program pembelajaran yang diterapkan melalui program BMPH membiasakan peserta didik untuk mencintai daerah melalui historis culture yang dipelajari dan melakukan kunjungan langsung ke situs megalit, belajar menggunakan budaya daerah yang merupakan kebanggaan sebagai pewaris budaya pada generasi berikutnya. Dengan demikian pembelajaran berbasis latar belakang historis bagi peserta didik di Sekolah Menengah Pertama (SMPN ) 1 di kabupaten Sigi berdasarkan hasil pre tes dan post tes mampu meningkatkan pengetahuan, dan sikap siswa dan mempraktekan menjaga warisan budaya leluhur melalui pewarisan pendidikan.

\section{KESIMPULAN}

Kegiatan Pengabdian melalui program BMPH pada peserta didik di SMPN 1 kabupaten sigi Sulawesi Tengah berjalan dengan baik, peserta didik mengikuti program ini memberikan wawasan dalam bidang pengetahuan mengenai pembelajaran melalui sejarah budaya memberikan manfaat bagi peserta didik dalam mengembangkan wawasan cinta terhadap budaya daerah (lokal) sebagai wujud implementasi yaitu menjaga budaya masyarakat pada zaman pra sejarah melalui megalit lumpang batu situs Vatu Nonju dengan cara mempraktikan menjaga kebersihan lingkungan sekitar situs lumpang batu.

\section{SARAN}

Berkaitan dengan kajian historis sebuah daerah dan pentingnya pengenalan nilai-nilai budaya pada masa lampau kepada peserta didik di Sekolah menengah Pertama di kabupaten sigi, program BMPH harus dilaksanakan secara rutin dalam bentuk penyuluhan kepada pserta didik mengenai konten sejarah budaya daerah melalui program pelatihan, worhshop dan outbond bagi kegiatan-kegiatan berikutnya. 


\section{DAFTAR PUSTAKA}

Ahmad. AT. 2017. Urgensi Dan Relevansi Pembelajaran Sejarah Maritim Untuk wilayah Pedalaman. Paramita; Historical; Studies journal. ISSN-08540039

Depdiknas. 2003. Undang-Undang Sistem Pendidikan Nasional tahun 2003. Retrievid 30 oktober, 2011. From www.depdiknas.go.id

Herlina. 2018. Muatan Pada konten Lokal Pada materi pelajaran Bahasa Inggris.,. Jurnal paedagogia jurnal pendidikan volume 7, Nomor 1, Maret 2018

Furqon. 2014. Ethnopedadgogy. The Proceding Internasional Seminar. FKIP UNLAM. Press.)

Printina. IB. 2017. Strategi Pembelajaran sejarah Berbasis Lagu-Lagu Perjuangan Dalam konteks Kesadaran Nasionalisme. Vol 7, No 01. Jurnal Unipma

Susanto, 2014. Penanaman kearifan lokal dalam hal pelestarian Lingkungan Sebagai sumber Pembelajaran IPS di Sekolah. Preceding Internasional, Bandung 18 September 2014)

Supriatna. N. Ecopedagogy Membangun Kecerdasan Ekologis dalam Pembelajaran IPS. 2016: Rosda Karya. 